\title{
Application of DSC and GC methods for characterization of newly designed spray-dried pea protein-fat preparations formulated with different types of a carbohydrate component
}

\author{
Anna Brynda-Kopytowska ${ }^{1} \cdot$ Agata Górska $^{2}$ (D) Joanna Bryś ${ }^{2} \cdot$ Ewa Domian$^{1} \cdot$ Magdalena Wirkowska-Wojdyła $^{2} \cdot$ \\ Ewa Ostrowska-Ligęza ${ }^{2}$
}

Received: 8 October 2017 / Accepted: 7 June 2018/Published online: 14 June 2018

(c) The Author(s) 2018

\begin{abstract}
In the study, spray-dried fat-filled protein-based powders consisting of pea protein isolate, vegetable oil and a carbohydrate component were obtained. Each group of model fat-filled powders was formulated with four different carbohydrates (Nutriose, inulin, polydextrose and trehalose). The formulations were kept for 6 months at $25^{\circ} \mathrm{C}$. In fats extracted from "fresh" powdered products and stored formulas, the following parameters have been determined: fatty acid composition, acid value, free fatty acid content, polyunsaturated-to-saturated fatty acids ratio and oxidation induction time in order to assess the stability of encapsulated fats. Fats extracted from pea protein-fat formulations showed a satisfactory hydrolytic stability. The most stable fats after storage were fats extracted from spray-dried fat-filled pea protein-based powders containing the mixture of palm and rapeseed oils formulated with inulin or trehalose. There is a significant relationship between the induction time and the unsaturated fatty acid content in fats extracted from fresh pea protein-fat formulas.
\end{abstract}

Keywords Fat-filled pea protein-based powders · Oxidative stability · Fatty acid composition · Hydrolytic stability

\section{Introduction}

Soluble fat powders are normally produced by spray-drying of an oil-in-water emulsion. The great advantage of powdered formulas is their stability, the ease of storage, transport and incorporating into food mixtures. Composition of the fat phase based on different fats or their mixtures in dry powder yields a rich assortment of fat formulations increasingly used in various food industries. Powdered mass may include both animal and vegetable fats. Vegetable fat powders, fat powders, creamers, replacers, toppings are fat-based formulations that are primarily produced on the basis of vegetable fats. There are

Agata Górska

agata_gorska@sggw.pl

1 Department of Food Engineering and Process Management, Faculty of Food Sciences, Warsaw University of Life Sciences, Nowoursynowska Str. 166, 02-787 Warsaw, Poland

2 Department of Chemistry, Faculty of Food Sciences, Warsaw University of Life Sciences, Nowoursynowska Str. 166, 02-787 Warsaw, Poland many categories of products in which the soluble fat formulation is an important ingredient. These are ice cream and desserts, milk candies, coffee, tea and cocoa coffees, dry concentrates and blends (soups and sauces, dips, seasonings, cake mixes, nutritional supplements, soluble cocktails and energy drinks). In recent years, vegetable proteins are presented as good replacement of animal proteins in protein-fat preparations. Incorporation of vegetable proteins to wall materials for encapsulation of sensitive substances reflects the current and innovative "green tendency" in food, cosmetics and pharmaceutical industries [1]. Proteins from legumes, besides for nutritional properties, have important functional properties, including gelling, emulsifying, fat-absorbing and waterbinding properties [2, 3]. Pea proteins show a good characteristic for their potential application, in particular for the production of adhesives, bioplastics, emulsifiers and wallforming materials for microencapsulation [4]. However, in the literature for microencapsulation uses, these proteins are generally associated with polysaccharides [1]. Indeed, polysaccharide/protein interactions give new functions to pea proteins without chemical or enzymatic modification, 
particularly solubility, foaming and surfactant properties [5]. Pea proteins alone or in association with polysaccharides are totally appropriate for the microencapsulation of hydrophilic [6, 7], hydrophobic [8] and triglyceride $[9,10]$ active core materials.

Protein-polysaccharide complexes allow optimum protection of the capsule core. Proteins, because of their surface properties, mainly play the role of an emulsion stabilizing colloid, and sugars-the role of filler in creating a solid powder matrix. Properly selected carbohydrate component can give a protein-fat powder with the desired characteristics, stable during storage. Speciality carbohydrates that allow great flexibility when replacing sugar in formulations have been developed commercially [11]. The majority of these carbohydrate ingredients are non-digestible oligo- or polysaccharides. These products are lower in calories than sugar, have soluble dietary fiber and, often, prebiotic properties. They include: gluco-polysaccharides (including polydextrose, resistant starches and maltodextrins) and fructo-oligosaccharides (FOS) (including inulin). Polydextrose is a low molecular weight randomly bonded polysaccharide of glucose with a calorific value of $1 \mathrm{kcal} \mathrm{g}^{-1}$ [12]. Nutriose, a registered trademark of Roquette Freres, is commercial example of RS-IV-resistant maltodextrin that is relatively soluble with "sugarlike" properties. Nutriose was designed to contain very low amounts of mono- and disaccharides' less than $0.5 \%$. The high stability and solubility, reaching more than $70 \% \mathrm{w} / \mathrm{w}$ in aqueous solution, of Nutriose makes it a versatile ingredient in food products for fortifying soluble dietary fiber. It is thermally stable at the $\mathrm{pH}$ of most food systems, even during UHT pasteurization. Inulin and fructooligosaccharides are the most studied prebiotics [13]. Inulin and low molecular weight FOS are interrelated $[14,15]$. FOS is characterized by a higher solubility than sucrose. FOS will not crystallize, precipitate or leave a dry or sandy feeling in the mouth. According to recent study reports, glassy trehalose enables producing stable encapsulated fat powders [16]. The important physical feature of trehalose is its high glass transition temperature reaching $107{ }^{\circ} \mathrm{C}$, which is the highest of all disaccharides [17].

Stable, soluble microencapsulated fat formulations can be extremely attractive, in terms of their functional properties, as the ingredient that enriches the various soluble powdery foods, cocktails and drinks, often characterized by the acid nature and content of salt minerals. In such preparations, stability of oils and fats is one of the most important parameters that determined the quality of the final product. Defining the relationship between the composition of spray-dried pea protein-fat preparations formulated with different types of a carbohydrate component and their properties, especially the stability of microencapsulated lipid fraction during storage of the products may be helpful in designing new stable powders and to optimize their manufacturing technologies.

Considering the above, the aim of the study was to evaluate the efficiency of newly designed double-wall material system (pea protein isolate/carbohydrate) in the aspect of microencapsulated oil stability. Spray-dried pea protein-fat preparations with different types of carbohydrste component (Nutriose, inulin, polidextrose and trehalose) were formulated. The formulations were kept for 6 months at $25{ }^{\circ} \mathrm{C}$. In fats extracted from fresh powdered products and stored formulas, the following parameters have been determined: oxidation induction time (IT), fatty acid composition, acid value, free fatty acid (FFA) content and polyunsaturated fatty acids (PUFA) to saturated fatty acids (SFA) ratio.

\section{Materials and methods}

\section{Chemicals and materials}

All the solvents and reagents were purchased from Avantor Performance Materials Poland S.A. (Gliwice, Poland) except for standard compounds which were supplied by Sigma-Aldrich (Saint Louis, MO, USA). Shortening AMADA L containing palm oil, rapeseed oil and hardened palm oil and rapeseed oil Maestro were purchased from the Bunge Company Poland (ZT Kruszwica S.A., Poland). Pea protein isolate NUTRALYS ${ }^{\circledR} \mathrm{S} 85 \mathrm{~F}$ and wheat dextrinsoluble fiber NUTRIOSE ${ }^{\circledR}$ FB06 were kindly donated by Roquette Poland sp. z o.o. Polydextrose STA-LITE R90 (Tate and Lyle USA) was obtained from Brenntag, Poland. Inulin ORAFTI GR (Orafti, Belgium) and trehalose (Hayashibara, Japan) were obtained from Hortimex, Poland. All the solvents and reagents used in analyses were of chromatographic or analytical grade.

\section{Methods}

\section{Experimental design}

The experimental design consisted of eight unique trials. The spray-dried fat-filled pea protein-based powders consisted of pea protein isolate (PPI), vegetable oil and soluble fiber as a carbohydrate component. The experimental design included two compositional variants, where the oil fraction was made up of blend of palm and rapeseed (PR) oils and rapeseed (R) oil as presented in Table 1. Each group of model fat-filled powders was formulated with four different carbohydrates [Nutriose $(\mathrm{N})$, inulin $(\mathrm{I})$, polydextrose (D), and trehalose (T)], wherein a carbohydrate-toprotein-material ratio was at 5.3:1 in all cases. 
Table 1 Experimental design of the formulations

\begin{tabular}{|c|c|c|c|c|c|c|c|c|}
\hline \multirow{2}{*}{$\begin{array}{l}\text { Code of } \\
\text { powder }\end{array}$} & \multicolumn{2}{|c|}{ Protein } & \multicolumn{2}{|l|}{ Fat } & \multicolumn{2}{|c|}{ Carbohydrate } & \multirow{2}{*}{$\begin{array}{l}\text { Carbohydrate-to-protein-material } \\
\text { ratio }\end{array}$} & \multirow{2}{*}{$\begin{array}{l}\text { Carbohydrate-to-fat-material } \\
\text { ratio }\end{array}$} \\
\hline & Type $^{\mathrm{a}}$ & $\begin{array}{l}\text { Content/ } \\
\%\end{array}$ & Type $^{\text {b }}$ & $\begin{array}{l}\text { Content/ } \\
\%\end{array}$ & Type $^{c}$ & $\begin{array}{l}\text { Content/ } \\
\%\end{array}$ & & \\
\hline PR_N & PPI & 7.5 & PR & 52.5 & $\mathrm{~N}$ & 40 & $5.3: 1$ & $0.8: 1$ \\
\hline PR_I & PPI & 7.5 & PR & 52.5 & I & 40 & $5.3: 1$ & $0.8: 1$ \\
\hline PR_D & PPI & 7.5 & PR & 52.5 & $\mathrm{D}$ & 40 & $5.3: 1$ & $0.8: 1$ \\
\hline PR_T & PPI & 7.5 & PR & 52.5 & $\mathrm{~T}$ & 40 & $5.3: 1$ & $0.8: 1$ \\
\hline R_N & PPI & 7.5 & $\mathrm{R}$ & 52.5 & $\mathrm{~N}$ & 40 & $5.3: 1$ & $0.8: 1$ \\
\hline R_I & PPI & 7.5 & $\mathrm{R}$ & 52.5 & I & 40 & $5.3: 1$ & $0.8: 1$ \\
\hline R_D & PPI & 7.5 & $\mathrm{R}$ & 52.5 & $\mathrm{D}$ & 40 & $5.3: 1$ & $0.8: 1$ \\
\hline R_T & PPI & 7.5 & $\mathrm{R}$ & 52.5 & $\mathrm{~T}$ & 40 & 5.3:1 & $0.8: 1$ \\
\hline
\end{tabular}

${ }^{\mathrm{a}} P P I$ pea protein isolate

${ }^{\mathrm{b}} P R$ blend of palm oil and rapeseed oil, $R$ rapeseed oil

${ }^{\mathrm{c}} N$ Nutriose, $I$ inulin, $D$ polydextrose, $T$ trehalose

\section{Preparation of model emulsions and fat-filled pea protein- based powders}

Model oil-in-water emulsions (target $30 \% \mathrm{w} / \mathrm{w}$ total solids, comprising pea protein, oil and soluble fiber) were prepared as follows. Carbohydrate powder was dissolved in hot water at $60{ }^{\circ} \mathrm{C}$, using a paddle agitator to aid reconstitution. Pea protein isolate was then added slowly during mixing, and the mixture was moved to cold storage at $5{ }^{\circ} \mathrm{C}$ for $12 \mathrm{~h}$ for the hydration of components. The water phase was tempered to $60{ }^{\circ} \mathrm{C}$ before addition of the fat component. When blend of palm and rapeseed oils was used, it was melted in a separate vessel before addition. The mix was agitated using Ultra-Turrax (IKA T18 Basic, Wilmington, USA) at 13,000 rpm for $2 \mathrm{~min}$, homogenized using a two-stage homogeniser (Panda $2 \mathrm{~K}$; Niro Soavi, Italy) using a first-stage pressure of $60 \mathrm{MPa}$ and a second-stage pressure of $20 \mathrm{MPa}$. The emulsions were spray-dried in a lab-scale Niro Spray dryer (Model MOBILE MINOR ${ }^{\mathrm{TM}}$ Niro A/S, Denmark), equipped with a rotary atomisation system and co-current drying, with a typical water evaporation rate of $1.5-2 \mathrm{~h}^{-1}$. An inlet air temperature of $150 \pm 3{ }^{\circ} \mathrm{C}$ and an outlet air temperature of $60 \pm 2{ }^{\circ} \mathrm{C}$ were selected, and disk rotation was at approximately $20,000 \mathrm{rpm}$.

\section{Storage of powders}

The fat powders were stored for 6 months in barrier foil packages tightly closed using a vacuum welding/packaging machine PP-5.4 (Tepro, Poland). Bags made of four-layer foil (lacquer, paper, aluminum, PE-LD low-density polyethylene), constituting a barrier to light, water vapor and air, served as package for samples. Powder samples were stored at $25{ }^{\circ} \mathrm{C}$. Properties of powders were researching 7 days after drying and after 6 months of storage.

\section{Fat extraction}

The oil was extracted from powdered formulations using the Folch procedure [18], which has been slightly modified by Boselli et al. [19]. Approximately $10 \mathrm{~g}$ of the sample was homogenized with $100 \mathrm{~mL}$ of a chloroform/methanol solution $(1 / 1 \mathrm{v} / \mathrm{v})$ in a glass bottle sealed with a screw cap. The bottle was kept at $60{ }^{\circ} \mathrm{C}$ for $20 \mathrm{~min}$ before adding an additional $100 \mathrm{~mL}$ of chloroform. After $3 \mathrm{~min}$ of homogenization, the content of the mixture was filtered through the filter paper. The filtrate was mixed thoroughly with $70 \mathrm{~mL}$ of $1 \mathrm{M} \mathrm{KCl}$ solution and left overnight at $4{ }^{\circ} \mathrm{C}$ in order to achieve phase separation. The organic phase was collected and dried with a rotary evaporator at $40{ }^{\circ} \mathrm{C}$.

\section{Free fatty acids content}

Acid values were determined by titration of fat samples dissolved in the mixture of ethanol:diethyl ether $(1: 1, \mathrm{v} / \mathrm{v})$ with $0.1 \mathrm{M}$ ethanolic potassium hydroxide solution. FFA content was calculated based on acid values and the value of molar mass of oleic acid. Acid values were analyzed by the standard method according to the Polish Standard (PNEN ISO 660:2010) [20].

\section{Determination of fatty acid composition}

The determination of fatty acid composition was carried out by gas chromatographic (GC) analysis of fatty acid methyl esters (FAME). An YL6100 GC chromatograph equipped with a flame ionization detector and BPX-70 
capillary column of $0.20 \mathrm{~mm}$ i.d. $\times 60 \mathrm{~m}$ length and 0.25 $\mu \mathrm{m}$ film thickness was used. The oven temperature was programmed as follows: $60{ }^{\circ} \mathrm{C}$ for $5 \mathrm{~min}$, then it was increased by $10^{\circ} \mathrm{C} \mathrm{min}-1$ to $180{ }^{\circ} \mathrm{C}$; from $180{ }^{\circ} \mathrm{C}$ to $230{ }^{\circ} \mathrm{C}$ it was increased by $3{ }^{\circ} \mathrm{C} \mathrm{min}{ }^{-1}$; then kept at $230{ }^{\circ} \mathrm{C}$ for $15 \mathrm{~min}$. The temperature of the injector was $225{ }^{\circ} \mathrm{C}$, with a split ratio of $1: 100$, and the detector temperature was $250{ }^{\circ} \mathrm{C}$. Nitrogen flowing with the rate of $1 \mathrm{~mL} \mathrm{~min}^{-1}$ was used as the carrier gas. The identification of fatty acids was carried out using the lipid standard. Fatty acids were identified by comparing the relative retention times of FAME peaks with FAME chemical standard. The results were expressed as relative percentages of each fatty acid.

\section{DSC studies: oxidation induction time}

A differential scanning calorimeter (DSC Q20 TA) coupled with a high-pressure cell (pressure differential scanning calorimetry-PDSC) was applied to determine the oxidative stability of tested fats. The thermal parameters were obtained from the heat flow curves with the use of the Universal V4.5A (TA Instruments) program. Fat samples of 3-4 mg were weighted into an aluminum pan and placed in the sample chamber under oxygen atmosphere with an initial pressure of $1400 \mathrm{kPa}$ and with the $100 \mathrm{~mL} \mathrm{~min}^{-1}$ oxygen flow rate. The isothermal temperature for each sample was $120^{\circ} \mathrm{C}$. For each sample, the output was automatically recalculated and presented as amount of energy per $1 \mathrm{~g}$. The maximum PDSC oxidation time (induction time) was determined based on the maximum rate of oxidation (maximum rate of heat flow).

\section{Statistical analysis}

Relative standard deviation was calculated, where appropriate, for all data collected using Microsoft Excel 2012 Software. One-way analysis of variance ANOVA was performed using the Statgraphics Plus, version 5.1. Differences were considered to be significant at a $p$ value of 0.05 , according to Tukey's multiple range test. Additionally, program Statistica 10 (Statsoft) was used to evaluate and analyze the data obtained during this study. The Spearman's rank correlation $\left(r_{\mathrm{s}}\right)$ (a non-parametric correlation of non-normal distributions) was used to determine correlation between PUFA/SFA, FFA, IT, PUFA, monounsaturated fatty acids (MUFA), SFA and trans isomers of fatty acids (TRANS).

\section{Results and discussion}

In the study, spray-dried fat-filled pea protein-based powders consisting of pea protein isolate, vegetable oil and a carbohydrate component were formulated. The experimental design included two compositional variants, where the fat fraction was made up of blend of palm and rapeseed oils and rapeseed oil as presented in Table 1. As the result of the experiment, the following products were obtained: PR_N_formulas containing mixture of palm oil and rapeseed oil with Nutriose, PR_T_-formulas containing mixture of palm oil and rapeseed oil with trehalose, PR_D_formulas containing mixture of palm oil and rapeseed oil with dextrose, PR_I—formulas containing mixture of palm oil and rapeseed oil with inulin, $\mathrm{R} \_\mathrm{N}-$ formulas containing rapeseed oil and Nutriose, $R_{-} T$ - formulas containing rapeseed oil and trehalose, R_D-formulas containing rapeseed oil and dextrose, $R \_I-$ formulas containing rapeseed oil and inulin.

\section{Fatty acids composition}

The data of fatty acid composition of fats extracted from studied preparations are given in Tables 2, 3, Figs. 1 and 2. Fats isolated from preparations PR (PR_N, PR_I, PR_D, PR_T) contained from 44.7 to $47.8 \%$ of monounsaturated fatty acids (MUFA) and from 34.5 to $37.4 \%$ of saturated fatty acids (SFA). The predominant fatty acid in fats from PR preparations was oleic acid (C18:1 $\omega 9)$ which accounted from 43.98 to $47.15 \%$ of fatty acids, followed by palmitic acid (C16:0) which accounted from $28.65 \%$ to $31.19 \%$. Fats from PR preparations contained also 13.3 to $14.2 \%$ of polyunsaturated fatty acids (PUFA) including important essential fatty acids from $n-3$ and $n-6$ groups as $\alpha$-linolenic acid and linoleic acid. The content of linoleic acid in fats isolated from RP formulas ranged from 10.31 to $11.36 \%$, and $\alpha$-linolenic from 2.91 to $3.17 \%$. According to data presented in the literature [21], the palm oil contains from 49.9 to $54.7 \%$ saturated fatty acids, $37.1-39.2 \%$ of monounsaturated fatty acids and $8.1-10.5 \%$ of polyunsaturated fatty acids. It can be observed that fats extracted from pea protein-lipid preparations containing palm oil were characterized by higher amount of unsaturated fatty acids and lower content of saturated fatty acids. It is due to the fact that the fat isolated from PR formulas was the mixture of palm and rapeseed oils. In fats extracted from PR preparations, some amount of isomer of trans fatty acids, ranged from 3.60 to $4.67 \%$, was also determined.

The percentage of PUFA in fats from $\mathrm{R}$ preparations (R_N, R_I, R_D, R_T) ranged from 30.0 to $30.8 \%$. These fats contained also 7.4 to $9.0 \%$ of SFA and the 60.9 to $61.8 \%$ of MUFA. R preparations, which were the subject of 
Table 2 Fatty acids composition (\%) in fats extracted from fresh and stored for 6-month PR formulas

\begin{tabular}{lrrrrrrrr}
\hline Fatty acid & \multicolumn{1}{c}{ PR_N_0M } & \multicolumn{1}{c}{ PR_N_6M } & \multicolumn{1}{c}{ PR_T_0M } & \multicolumn{1}{c}{ PR_T_6M } & PR_D_0M & PR_D_6M & PR_I_0M & PR_I_6M \\
\hline C8:0 & $0.03 \pm 0.00$ & $0.02 \pm 0.02$ & $0.05 \pm 0.01$ & $0.04 \pm 0.01$ & $0.04 \pm 0.01$ & $0.03 \pm 0.00$ & $0.03 \pm 0.00$ & $0.03 \pm 0.00$ \\
C10:0 & $0.04 \pm 0.00$ & $0.01 \pm 0.01$ & $0.05 \pm 0.01$ & $0.04 \pm 0.01$ & $0.04 \pm 0.01$ & $0.03 \pm 0.00$ & $0.04 \pm 0.01$ & $0.03 \pm 0.00$ \\
C12:0 & $0.31 \pm 0.07$ & $0.31 \pm 0.01$ & $0.45 \pm 0.10$ & $0.31 \pm 0.04$ & $0.35 \pm 0.02$ & $0.26 \pm 0.03$ & $0.32 \pm 0.02$ & $0.27 \pm 0.00$ \\
C14:0 & $0.82 \pm 0.05$ & $0.73 \pm 0.04$ & $0.98 \pm 0.14$ & $0.76 \pm 0.02$ & $0.83 \pm 0.03$ & $0.73 \pm 0.01$ & $0.80 \pm 0.05$ & $0.72 \pm 0.00$ \\
C15:0 & $0.05 \pm 0.00$ & $0.02 \pm 0.03$ & $0.04 \pm 0.00$ & $0.04 \pm 0.01$ & $0.05 \pm 0.00$ & $0.04 \pm 0.00$ & $0.04 \pm 0.01$ & $0.05 \pm 0.01$ \\
C16:0 & $28.83 \pm 0.21$ & $28.65 \pm 0.35$ & $31.19 \pm 1.62$ & $29.08 \pm 0.19$ & $29.61 \pm 0.37$ & $29.04 \pm 0.35$ & $29.31 \pm 0.26$ & $28.71 \pm 0.01$ \\
C16:1c & $0.13 \pm 0.06$ & $0.19 \pm 0.01$ & $0.18 \pm 0.01$ & $0.19 \pm 0.01$ & $0.19 \pm 0.01$ & $0.18 \pm 0.00$ & $0.18 \pm 0.01$ & $0.19 \pm 0.00$ \\
C17:0 & $0.09 \pm 0.00$ & $0.11 \pm 0.01$ & $0.11 \pm 0.01$ & $0.08 \pm 0.00$ & $0.12 \pm 0.00$ & $0.11 \pm 0.01$ & $0.09 \pm 0.01$ & $0.13 \pm 0.01$ \\
C18:0 & $4.28 \pm 0.13$ & $4.13 \pm 0.04$ & $4.07 \pm 0.16$ & $4.11 \pm 0.04$ & $4.20 \pm 0.09$ & $4.18 \pm 0.04$ & $4.23 \pm 0.08$ & $4.33 \pm 0.04$ \\
C18:1t & $3.60 \pm 1.08$ & $3.88 \pm 0.45$ & $4.67 \pm 0.12$ & $4.50 \pm 0.21$ & $4.11 \pm 0.56$ & $3.70 \pm 1.32$ & $4.03 \pm 1.19$ & $4.67 \pm 0.01$ \\
C18:1n9c & $47.15 \pm 2.37$ & $46.57 \pm 0.24$ & $43.98 \pm 1.29$ & $46.17 \pm 0.30$ & $46.16 \pm 0.36$ & $46.87 \pm 1.36$ & $46.50 \pm 0.95$ & $45.74 \pm 0.06$ \\
C18:2n6c & $11.36 \pm 0.03$ & $11.05 \pm 0.07$ & $10.37 \pm 0.18$ & $10.62 \pm 0.22$ & $10.31 \pm 0.08$ & $10.81 \pm 0.23$ & $10.41 \pm 0.24$ & $10.97 \pm 0.01$ \\
C18:3n3c & $2.53 \pm 0.64$ & $3.17 \pm 0.18$ & $2.91 \pm 0.05$ & $3.06 \pm 0.09$ & $2.98 \pm 0.07$ & $2.95 \pm 0.04$ & $3.01 \pm 0.00$ & $3.02 \pm 0.01$ \\
C20:0 & $0.31 \pm 0.29$ & $0.54 \pm 0.05$ & $0.44 \pm 0.06$ & $0.51 \pm 0.01$ & $0.49 \pm 0.00$ & $0.53 \pm 0.02$ & $0.47 \pm 0.01$ & $0.55 \pm 0.00$ \\
C20:1c & $0.51 \pm 0.07$ & $0.59 \pm 0.01$ & $0.54 \pm 0.04$ & $0.54 \pm 0.01$ & $0.58 \pm 0.01$ & $0.58 \pm 0.04$ & $0.56 \pm 0.03$ & $0.61 \pm 0.01$ \\
\hline
\end{tabular}

$P R$ blend of palm oil and rapeseed oil, $N$ Nutriose, $I$ inulin, $D$ polydextrose, $T$ trehalose

Data expressed as mean \pm standard deviation

Table 3 Fatty acids composition (\%) in fats extracted from fresh and stored for 6-month $R$ formulas

\begin{tabular}{|c|c|c|c|c|c|c|c|c|}
\hline Fatty acid & R_N_OM & R_N_6M & R_T_0M & R_T_6M & R_D_0M & R_D_6M & R_I_0M & R_I_6M \\
\hline C16:0 & $5.42 \pm 0.28$ & $5.48 \pm 0.00$ & $5.52 \pm 0.64$ & $5.08 \pm 0.06$ & $5.77 \pm 0.69$ & $4.91 \pm 0.17$ & $6.44 \pm 1.92$ & $4.80 \pm 0.01$ \\
\hline $\mathrm{C} 16: 1 \mathrm{c}$ & $0.24 \pm 0.01$ & $0.23 \pm 0.01$ & $0.22 \pm 0.05$ & $0.22 \pm 0.00$ & $0.25 \pm 0.04$ & $0.22 \pm 0.01$ & $0.31 \pm 0.09$ & $0.21 \pm 0.00$ \\
\hline C17:0 & $0.12 \pm 0.01$ & $0.10 \pm 0.01$ & $0.12 \pm 0.01$ & $0.12 \pm 0.01$ & $0.14 \pm 0.01$ & $0.11 \pm 0.00$ & $0.14 \pm 0.03$ & $0.11 \pm 0.00$ \\
\hline C17:1c & $0.06 \pm 0.01$ & $0.08 \pm 0.00$ & $0.07 \pm 0.01$ & $0.07 \pm 0.01$ & $0.06 \pm 0.01$ & $0.06 \pm 0.00$ & $0.06 \pm 0.00$ & $0.07 \pm 0.01$ \\
\hline C18:0 & $1.98 \pm 0.02$ & $1.95 \pm 0.01$ & $1.87 \pm 0.20$ & $1.87 \pm 0.01$ & $1.94 \pm 0.11$ & $1.86 \pm 0.01$ & $1.86 \pm 0.17$ & $1.84 \pm 0.01$ \\
\hline C18:1n9c & $59.93 \pm 0.03$ & $59.57 \pm 0.04$ & $60.18 \pm 0.42$ & $59.87 \pm 0.04$ & $59.91 \pm 0.59$ & $59.93 \pm 0.06$ & $59.29 \pm 1.00$ & $60.02 \pm 0.07$ \\
\hline C18:2n6c & $19.67 \pm 0.07$ & $19.44 \pm 0.03$ & $19.49 \pm 0.15$ & $19.65 \pm 0.01$ & $19.40 \pm 0.23$ & $19.75 \pm 0.15$ & $19.68 \pm 0.08$ & $19.84 \pm 0.02$ \\
\hline $\mathrm{C} 18 \mathrm{~s} 3 \mathrm{n} 3 \mathrm{c}$ & $9.86 \pm 0.19$ & $10.17 \pm 0.02$ & $9.96 \pm 0.11$ & $10.19 \pm 0.00$ & $9.94 \pm 0.04$ & $10.18 \pm 0.02$ & $9.84 \pm 0.22$ & $10.15 \pm 0.02$ \\
\hline C20:0 & $0.62 \pm 0.02$ & $0.67 \pm 0.01$ & $0.57 \pm 0.01$ & $0.65 \pm 0.01$ & $0.59 \pm 0.12$ & $0.65 \pm 0.00$ & $0.53 \pm 0.16$ & $0.65 \pm 0.00$ \\
\hline $\mathrm{C} 20: 1 \mathrm{c}$ & $1.45 \pm 0.04$ & $1.53 \pm 0.03$ & $1.37 \pm 0.11$ & $1.51 \pm 0.02$ & $1.36 \pm 0.24$ & $1.52 \pm 0.00$ & $1.25 \pm 0.38$ & $1.51 \pm 0.01$ \\
\hline$C 20: 3 n 3 c$ & $0.31 \pm 0.02$ & $0.37 \pm 0.00$ & $0.28 \pm 0.01$ & $0.37 \pm 0.00$ & $0.30 \pm 0.07$ & $0.38 \pm 0.01$ & $0.30 \pm 0.10$ & $0.38 \pm 0.01$ \\
\hline C20:4n6 & $0.38 \pm 0.03$ & $0.44 \pm 0.00$ & $0.37 \pm 0.07$ & $0.43 \pm 0.01$ & $0.36 \pm 0.10$ & $0.44 \pm 0.00$ & $0.33 \pm 0.12$ & $0.44 \pm 0.01$ \\
\hline
\end{tabular}

$R$ rapeseed oil, $N$ Nutriose, $I$ inulin, $D$ polydextrose, $T$ trehalose

Data expressed as mean \pm standard deviation

the research, are rich source of essential unsaturated fatty acids, such as, among others, linoleic acid (C18:2 $\omega 6)$ and $\alpha$-linolenic acid (18:3 $\omega 3$ ). The content of linoleic acid in fats isolated from $\mathrm{R}$ preparations ranged from 19.40 to $19.84 \%$, whereas the $\alpha$-linolenic acid was determined at the level 9.84 to $10.19 \%$. These fats contained also oleic acid, belonging to monounsaturated fatty acids in significant amounts (from 59.57 to $60.18 \%$ ). According to data given in the literature [22], the content of $\alpha$-linolenic acid, linoleic and oleic acid in refined rapeseed oil reached 6.1, 15.1 and $67.9 \%$, respectively. It can be observed that fats extracted from $\mathrm{R}$ preparations were characterized by similar fatty acid composition to rapeseed oil. In these fats, no isomers of trans fatty acids were determined.

Neither the storage time nor the type of carbohydrate used in the preparation has a statistically significant effect on the changes in fatty acid composition of the fats extracted from these formulations. Generally, it can be 
Fig. 1 Content of fatty acids (SFA saturated fatty acids, MUFA monounsaturated fatty acids, PUFA polyunsaturated fatty acids, TRANS isomers of trans fatty acids) for fats from PR formulas, $P R$ blend of palm oil and rapeseed oil, $N$ Nutriose, $I$ inulin, $D$ polydextrose, $T$ trehalose. *The different letters indicate significantly different values for SFA, MUFA, PUFA and TRANS $(p<0.05)$
Fig. 2 Content of fatty acids (SFA saturated fatty acids, MUFA monounsaturated fatty acids, PUFA polyunsaturated fatty acids) for fats from $R$ formulas. $R$ rapeseed oil, $N$ Nutriose, $I$ inulin,

$D$ polydextrose, $T$ trehalose.

*The different letters indicate significantly different values for SFA, MUFA, PUFA $(p<0.05)$
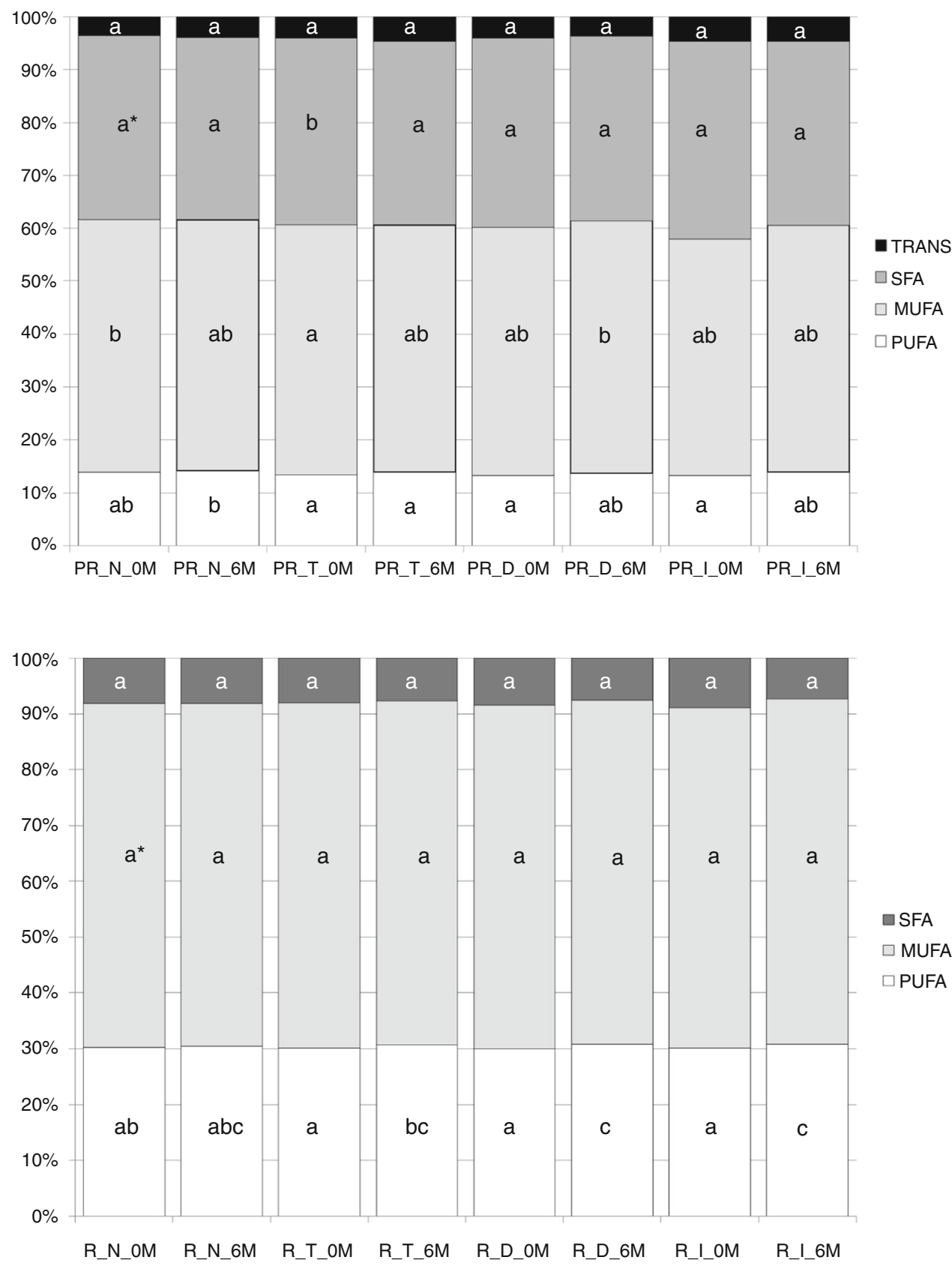

stated that protein-lipid preparations were characterized by the desired composition of fatty acids, which did not change during storage. Thus, it can be concluded that pea protein-carbohydrate matrixes used in powdered formulas had protective effect on the encapsulated fat. The results are in agreement with these reported by Augustin et al. [23], who observed that the combination of proteins with carbohydrates as a carrier material favors better stability of microencapsulated fish oil. In the study of Karaca et al. [24], it has been observed that flaxseed oil could be efficiently entrapped with maltodextrin combined with chickpea protein isolate or lentil isolate by spray drying or freeze drying, providing a protective effect against oxidation during storage. Various studies have shown that a wall system consisting of protein in conjunction with carbohydrates is effecting in stabilizing encapsulated fat during storage of spray-dried powder [16, 25, 26].

In the study, the PUFA SFA ${ }^{-1}$ ratio for fats extracted from protein-lipid preparations was also determined as an important indicator of the nutritional value of food products (Table 4). In the study, fat extracted from the formulations containing palm oil in their composition was 
Table 4 PUFA SFA ${ }^{-1}$ ratio for fats from PR and $R$ formulas

\begin{tabular}{lllllllll}
\hline Time of storage/months & PR_N & PR_T & PR_D & PR_I & R_N & R_T & R_D & R_I \\
\hline 0 & 0.40 & 0.38 & 0.37 & 0.36 & 3.72 & 3.73 & 3.56 & 3.36 \\
6 & 0.41 & 0.40 & 0.39 & 0.40 & 3.72 & 3.98 & 4.08 & 4.16 \\
\hline
\end{tabular}

PUFA polyunsaturated fatty acid, $S F A$ saturated fatty acid, $P R$ blend of palm oil and rapeseed oil, $R$ rapeseed oil, $N$ Nutriose, $I$ inulin, $D$ polydextrose, $T$ trehalose characterized by a low PUFA-to-SFA ratio reaching 0.36 to 0.41 , whereas in the case of fat from the preparations containing rapeseed oil higher value of PUFA SFA ${ }^{-1}$ ranging from 3.36 to 4.16 was observed.

\section{Oxidative stability}

Oxidative stability of oils and fats is one of the most important parameters for product quality assessment; thus, the selection of the best coating material is an essential factor in obtaining microencapsulated fat that is effectively protected against oxidation. A number of methods for such an assessment have been developed [27], among which differential scanning calorimetry is one of the most frequently used [28]. There are reports saying that the DSC data for vegetable oil oxidation correlate well with Rancimat and electron spin resonance (ESR) spectroscopy results [27-31]. The results of PDSC measurements are shown in Fig. 3. The DSC curves presenting the oxidation induction times are presented in Figs. 4, 5, 6 and 7.

Induction time can be used as primary parameter for the assessment of the resistance of tested fats to their thermal oxidative decomposition. Generally, samples with longer induction times are more stable than those for which the induction time obtained at the same temperature is shorter [32-36]. The higher degree of unsaturation of fatty acids makes these fats more susceptible to oxidation processes. Taking into account the results of the regression analysis, it can be stated that the induction time of fats isolated from pea protein-fat preparations is related to the PUFA SFA ${ }^{-1}$ ratio and in this case a linear relationship can be observed. This dependency is matched to the model at $86.34 \%\left(R^{2}\right)$ (Fig. 8).

The PDSC tests for fats extracted from formulas after 6 months of storage, performed at isothermal temperature of $120{ }^{\circ} \mathrm{C}$, showed that the induction time increased in
Fig. 3 Oxidation induction time of fats from PR and $R$ formulas. $P R$ blend of palm oil and rapeseed oil, $R$ rapeseed oil, $N$ Nutriose, $I$ inulin,

$D$ polydextrose, $T$-trehalose. Different letters indicate that the samples are significantly different at $p<0.05$ (separately for PR formulas and for $R$ formulas)

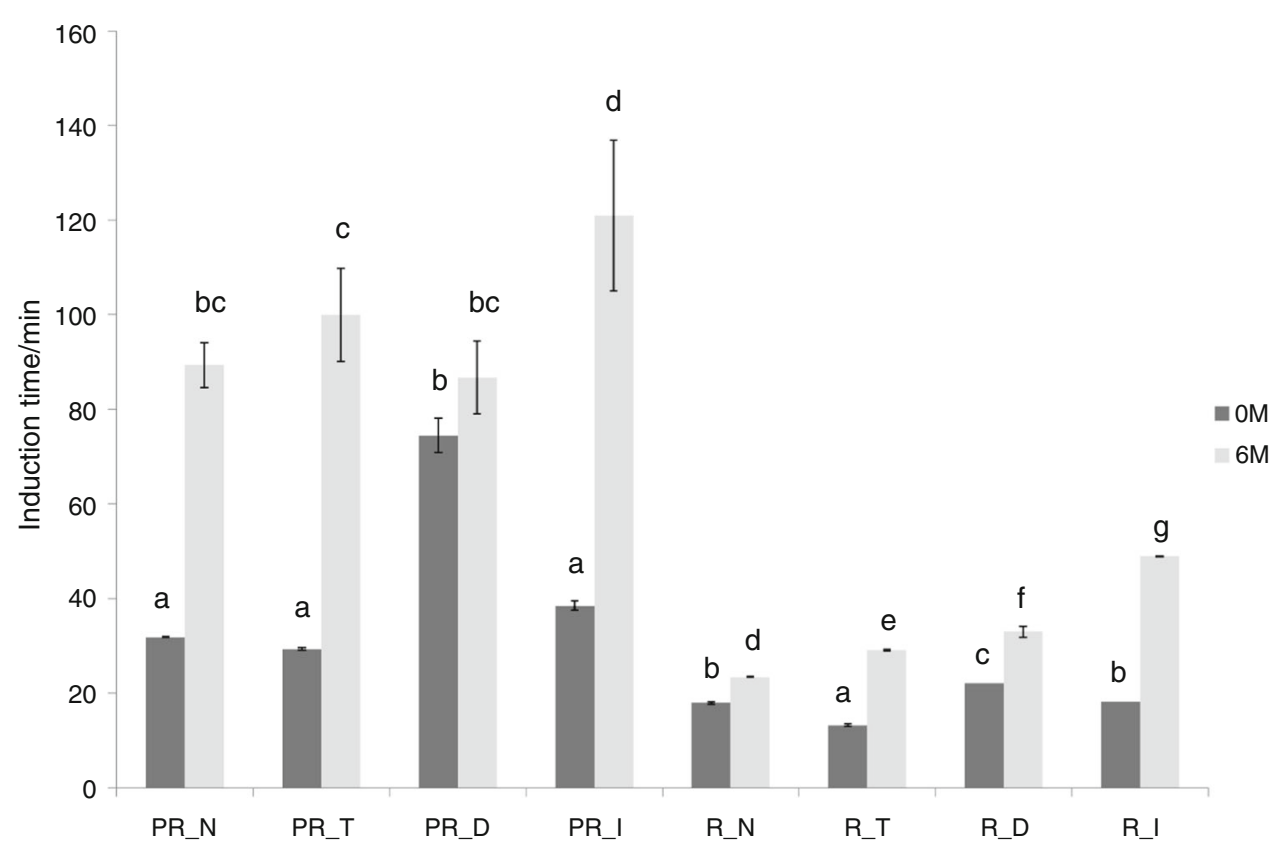


Fig. 4 DSC curves of oxidation induction time of fats from fresh PR formulas (1 PR_N-blend of palm oil and rapeseed oil with Nutriose, 2 PR_T_blend of palm oil and rapeseed oil with trehalose, 3 PR_D_-blend of palm oil and rapeseed oil with polydextrose, 4 PR_I-blend of palm oil and rapeseed oil with inulin)

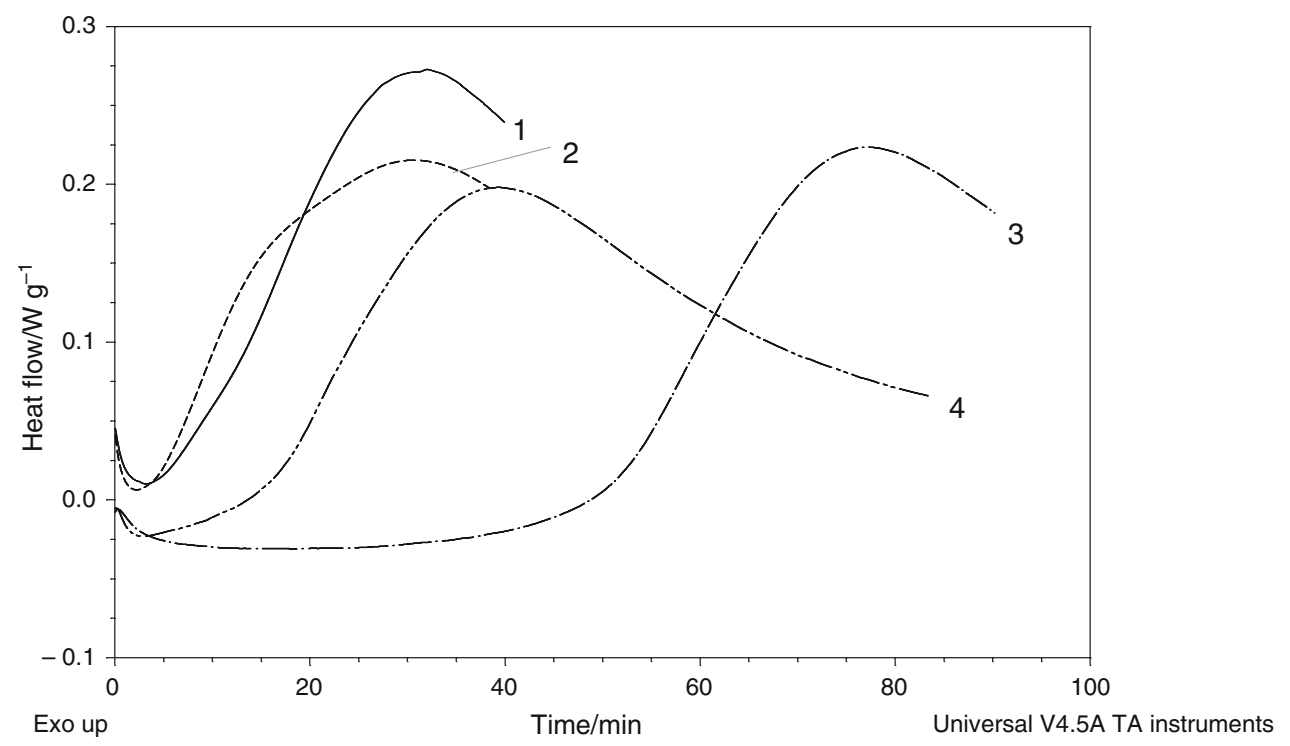

Fig. 5 DSC curves of oxidation induction time of fats from PR formulas after 6-month storage (1 PR_N_blend of palm oil and rapeseed oil with Nutriose, 2 PR_T_-blend of palm oil and rapeseed oil with trehalose, 3 PR_D—blend of palm oil and rapeseed oil with polydextrose, 4 PR_I_-blend of palm oil and rapeseed oil with inulin)

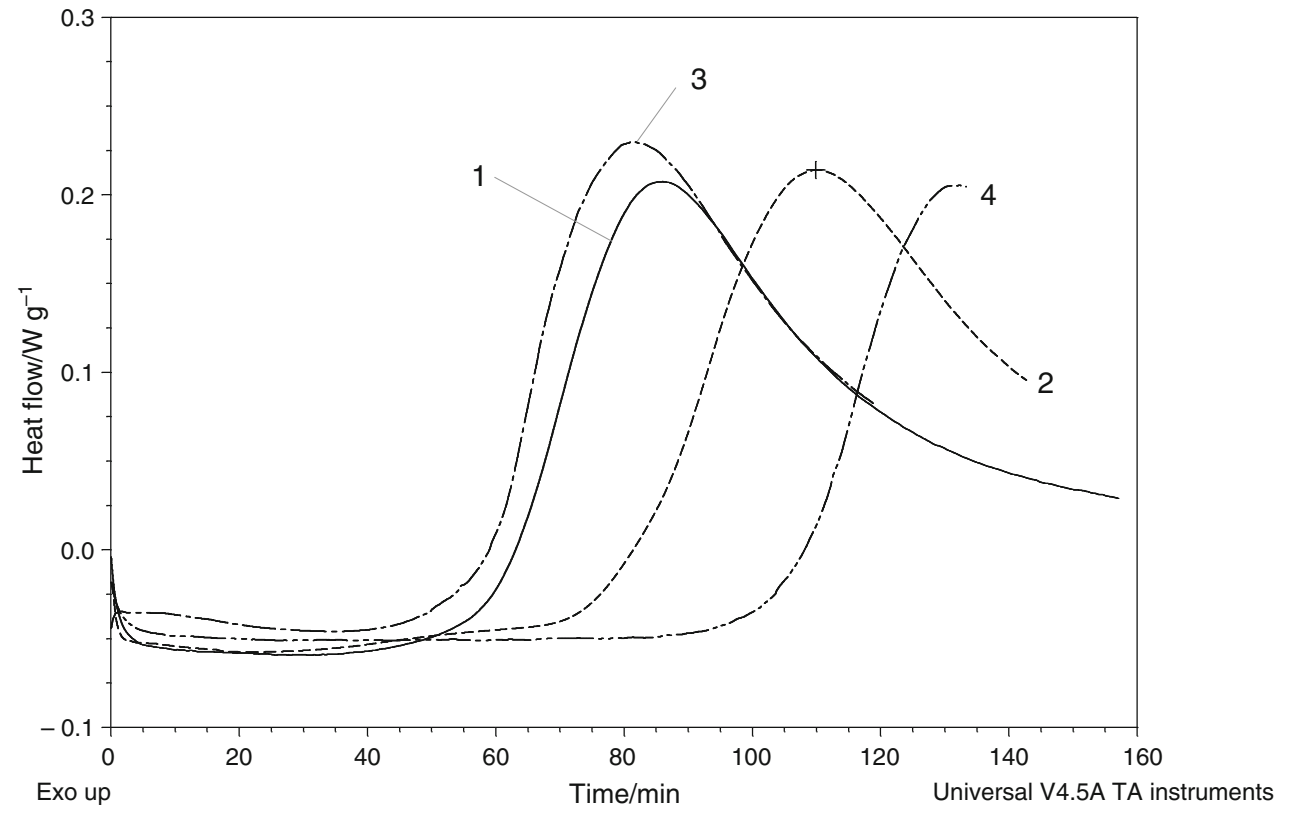

comparison with fats from fresh samples. Fats extracted from fresh capsules are therefore less stable compared to fats obtained from formulations stored for 6 months. The presumed cause of the increase in oxidative stability may be the presence of melanoidin-compounds formed during the Maillard reaction. Such compounds can arise when both protein and reducing sugars are present in the sample. The high temperature that is used during the process of spray-drying and the shelf life of 6 months are favorable to their formation. Literature data on hazelnuts report that the oxidative stability level of oil extracted from roasted hazelnuts seemed to be comparable or even higher than previously reported [37]. It could be partially explained by the Maillard reaction products formation through the interaction of proteins with reducing sugars during hightemperature treatment [38]. The increase in oxidative 
Fig. 6 DSC curves of oxidation induction time of fats from fresh $R$ formulas (1 R_N-rapeseed oil with Nutriose, 2 R_Trapeseed oil with trehalose, 3 R_D—rapeseed oil with polydextrose, 4 R_I-rapeseed oil with inulin)

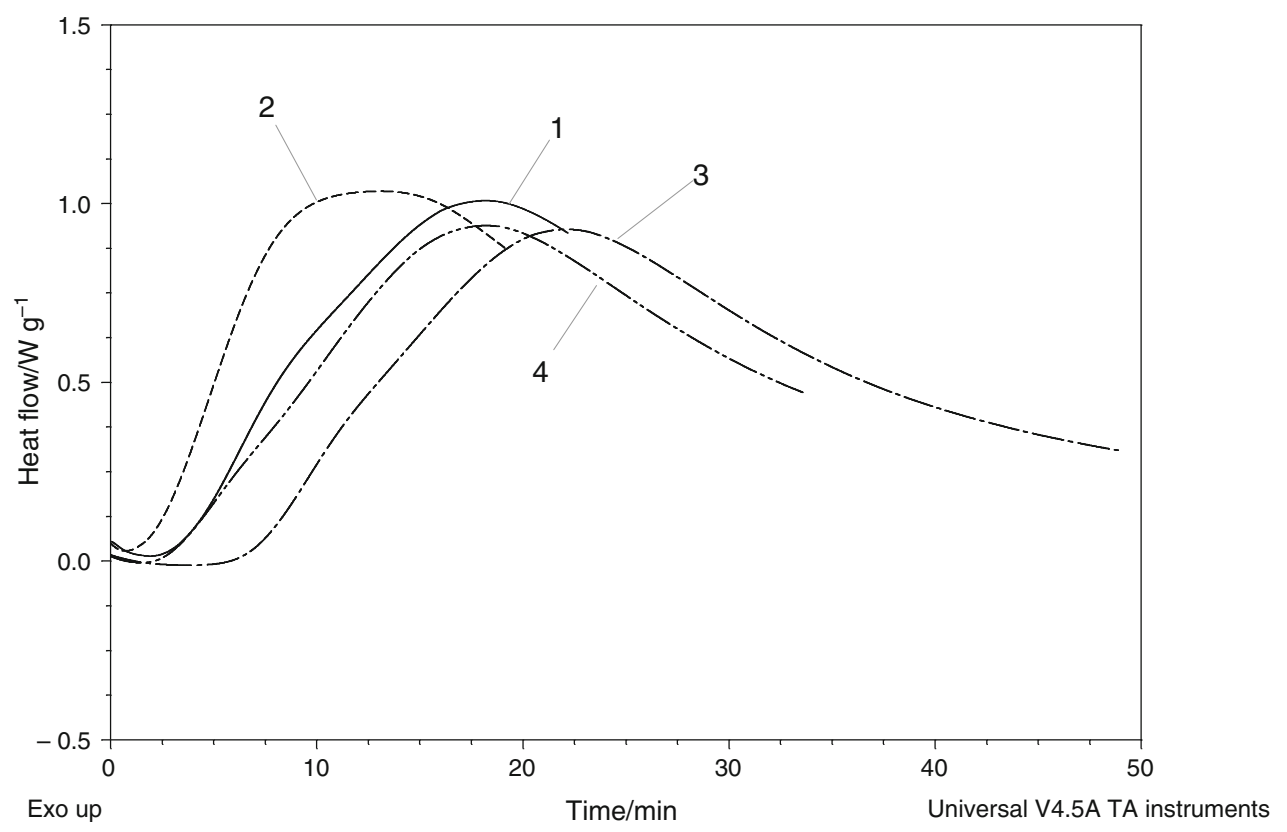

Fig. 7 DSC curves of oxidation induction time of fats from $R$ formulas after 6-month storage (1 R_N_rapeseed oil with Nutriose, 2 R_T_rapeseed oil with trehalose, 3 R_D—rapeseed oil with polydextrose, 4 R_I-rapeseed oil with inulin)

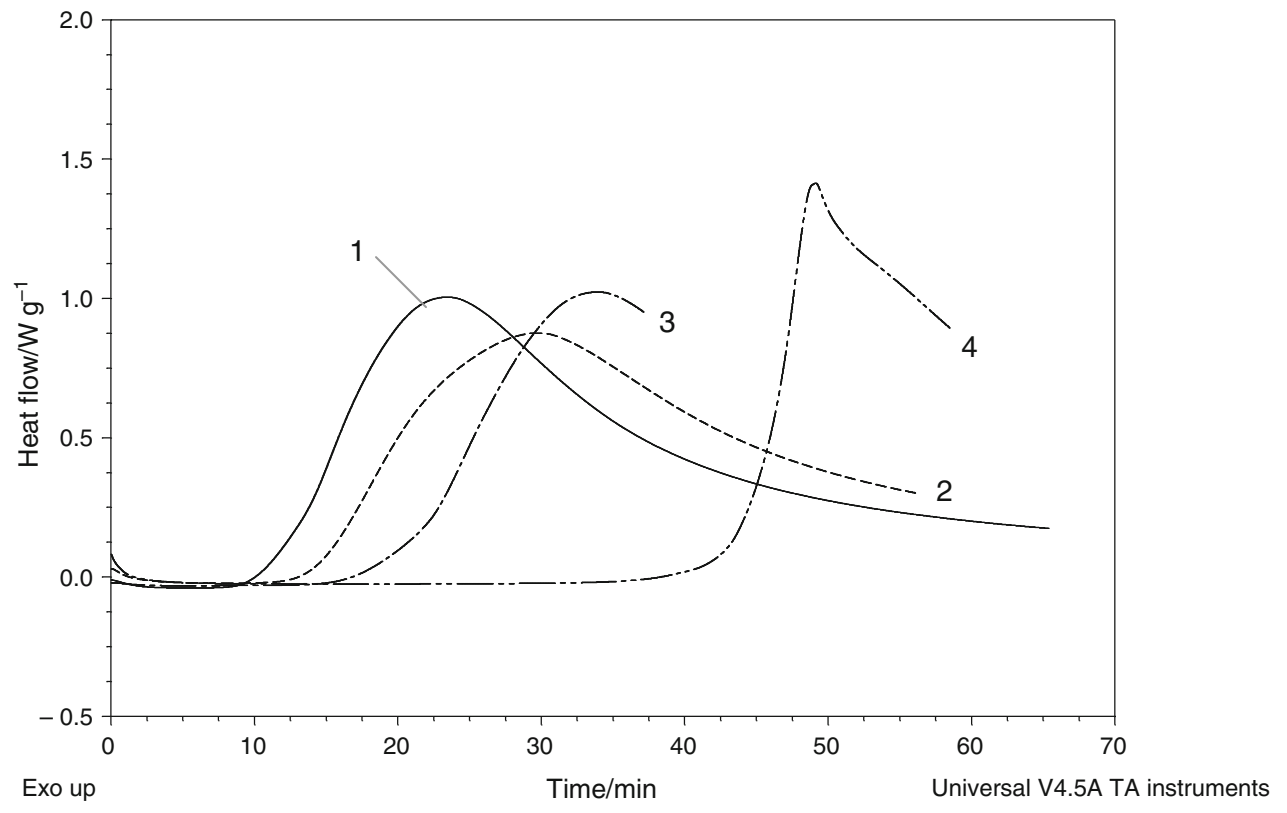

stability is particularly noticeable in the case of fat extracted from PR formulations containing inulin or trehalose as a carbohydrate component in the matrices. Inulin can take part in reactions with other components, such as the amino group of pea proteins in the Maillard reaction [39]. As reported by Michalska and Zieliński [40], melanoidins, products of non-enzymatic browning, reportedly show strong antioxidant activity which can affect positively oxidative stability of tested hazelnuts. According to the studies provided by Oku et al. [41], trehalose has a significant depression effect on the oxidation of unsaturated fatty acids through the weak interaction with 
Fig. 8 Linear correlation between obtained ratio PUFA $\mathrm{SFA}^{-1}$ and induction time of fats from $\mathrm{PR}$ and $\mathrm{R}$ formulas after 6 months of storage

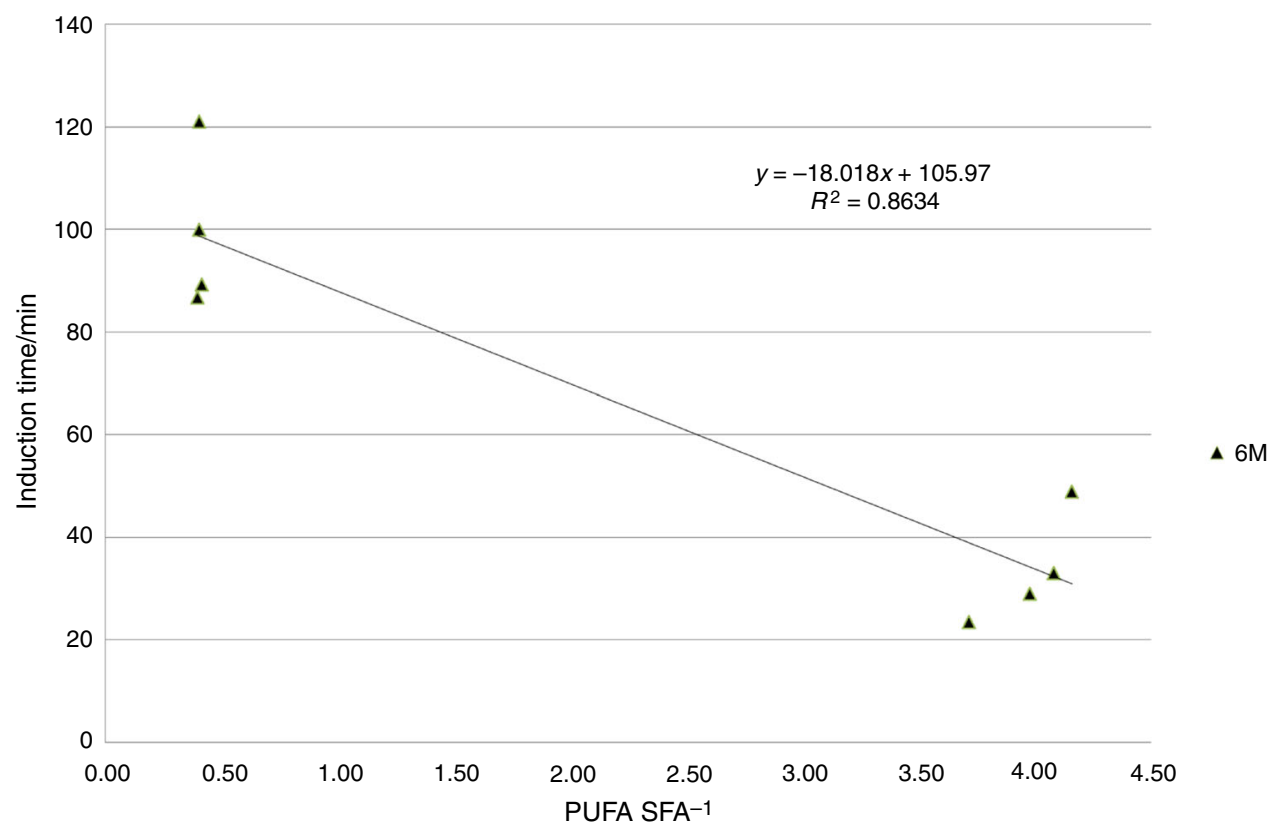

the double bond(s). ${ }^{1} \mathrm{H}-{ }^{1} \mathrm{H}$ NOESY measurements provided direct evidence for complexation of trehalose with linoleic acid. Computer modeling study indicates that trehalose forms a stable complex with a double bond through $\mathrm{OH} \cdots \pi$ and $\mathrm{CH} \cdots \mathrm{O}$ type of hydrogen bonding.

\section{Free fatty acids content}

The main components of fats are triacylglycerols. Fats also contain certain quantities of monoacylglycerols, diacylglycerols and free fatty acids. Hamam and Shahidi [42] suggested that the presence of free fatty acids may induce oxidation due to a catalytic effect of the carboxylic groups of the fatty acids on the formation of free radicals. The determinant of free fatty acids contents in fat is acid value $(\mathrm{AV})$. Acid value of tested fats from lipid-protein formulas amounted from 0.48 to $0.77 \mathrm{mg} \mathrm{KOH} \mathrm{g}^{-1}$ of fat. The acid value for the fats of all tested formulations was therefore below $4 \mathrm{mg} \mathrm{KOH} \mathrm{g}{ }^{-1}$, so it was within the standard (ISO 660: 2000). It can be stated that fats separated from pea protein-fat formulations were of satisfactory hydrolytic stability.
Fig. 9 Free fatty acids content for fats from PR and $R$ formulas. $P R$ blend of palm oil and rapeseed oil, $R$ rapeseed oil, $N$ Nutriose, $I$ inulin,

$D$ polydextrose, $T$ trehalose.

Different letters indicate that the samples are significantly different at $p<0.05$ (separately for PR formulas and for $R$ formulas)

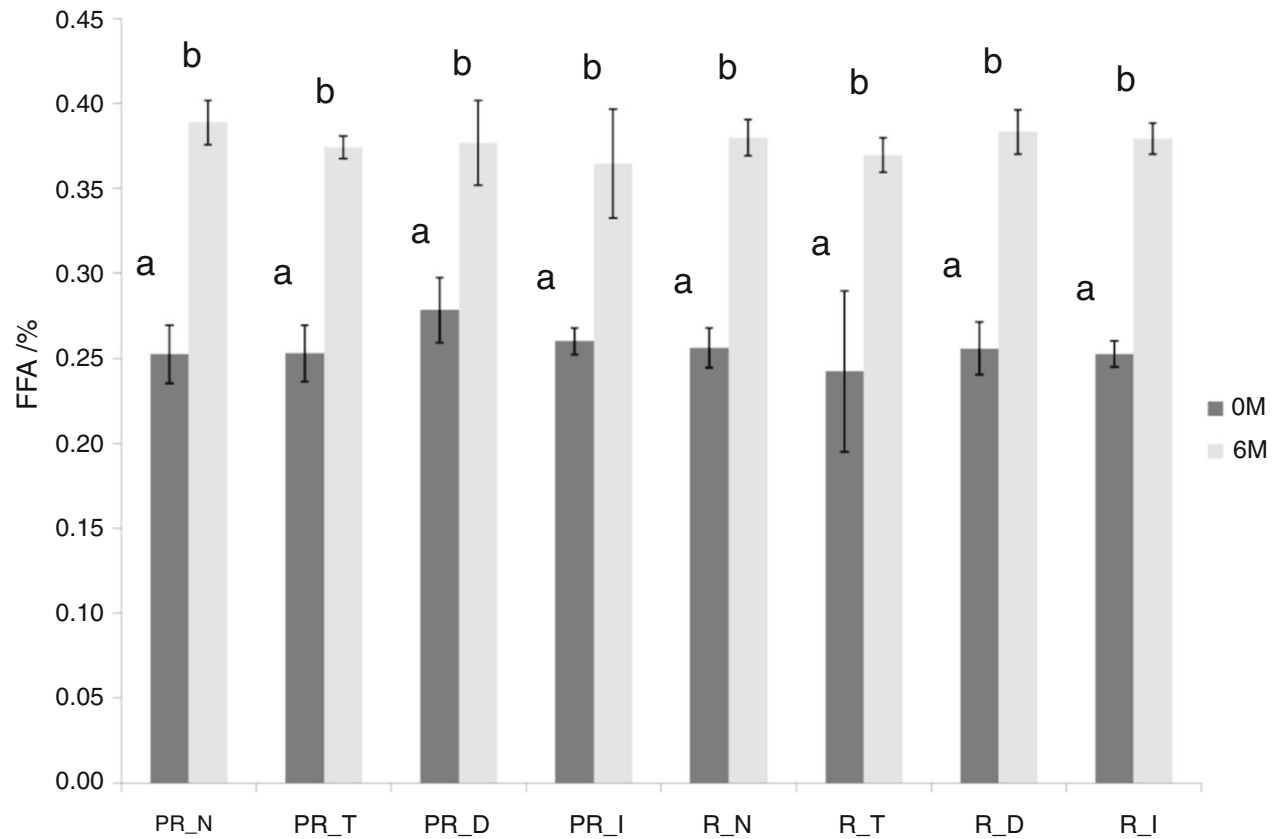


Table 5 The Spearman's rank correlation $\left(r_{\mathrm{s}}\right)$ (a non-parametric correlation of non-normal distributions) between PUFA/SFA, FFA, IT, PUFA, MUFA, SFA and TRANS in fats extracted from fresh formulas and from samples stored for 6 months

\begin{tabular}{|c|c|c|c|c|c|c|c|}
\hline & PUFA/SFA & FFA & IT & PUFA & MUFA & SFA & TRANS \\
\hline \multicolumn{8}{|l|}{0 month } \\
\hline PUFA/SFA & 1.00000 & -0.571429 & -0.785714 & 0.880952 & 1.00000 & -1.00000 & -0.938591 \\
\hline FFA & -0.57143 & 1.000000 & 0.333333 & -0.452381 & -0.57143 & 0.57143 & 0.545397 \\
\hline IT & -0.78571 & 0.333333 & 1.000000 & -0.928571 & -0.78571 & 0.78571 & 0.887856 \\
\hline PUFA & 0.88095 & -0.452381 & -0.928571 & 1.000000 & 0.88095 & -0.88095 & -0.938591 \\
\hline MUFA & 1.00000 & -0.571429 & -0.785714 & 0.880952 & 1.00000 & -1.00000 & -0.938591 \\
\hline SFA & -1.00000 & 0.571429 & 0.785714 & -0.880952 & -1.00000 & 1.00000 & 0.938591 \\
\hline TRANS & -0.93859 & 0.545397 & 0.887856 & -0.938591 & -0.93859 & 0.93859 & 1.000000 \\
\hline \multicolumn{8}{|l|}{6 months } \\
\hline PUFA/SFA & 1.00000 & 0.380952 & -0.619048 & 1.00000 & 0.857143 & -1.00000 & -0.786387 \\
\hline FFA & 0.38095 & 1.000000 & -0.333333 & 0.38095 & 0.380952 & -0.38095 & -0.380510 \\
\hline IT & -0.61905 & -0.333333 & 1.000000 & -0.61905 & -0.761905 & 0.61905 & 0.938591 \\
\hline PUFA & 1.00000 & 0.380952 & -0.619048 & 1.00000 & 0.857143 & -1.00000 & -0.786387 \\
\hline MUFA & 0.85714 & 0.380952 & -0.761905 & 0.85714 & 1.000000 & -0.85714 & -0.938591 \\
\hline SFA & -1.00000 & -0.380952 & 0.619048 & -1.00000 & -0.857143 & 1.00000 & 0.786387 \\
\hline TRANS & -0.78639 & -0.380510 & 0.938591 & -0.78639 & -0.938591 & 0.78639 & 1.000000 \\
\hline
\end{tabular}

Free fatty acid content was calculated based on acid values and the value of molar mass of oleic acid. The results of FFA content for the fat extracted from lipidprotein preparations are given in Fig. 9.

The content of free fatty acids in fats extracted from fresh protein-fat preparations ranged from 0.24 to $0.28 \%$. The storage time of tested formulations was the factor with the greatest influence on the acid value and hence on the content of free fatty acids. Statistically significant differences were observed between the free fatty acid content of fats obtained from the formulations stored for 6 months and the fats obtained from fresh preparations. Fats isolated from preparations stored for 6 months were characterized by the highest acid values and, consequently, by the highest content of free fatty acids. The content of free fatty acids ranged in this case from 0.36 to $0.39 \%$. Neither a carbohydrate type nor the type of fat incorporated into the preparation has a statistically significant effect on the FFA content in fats extracted from pea protein-fat preparations. The content of free fatty acids in fat extracted from PR preparations was lower than the content of FFA in palm fat. According to Mba et al. [21], the content of free fatty acids in palm oil ranges from 3.17 to $5.0 \%$. The acid value of fats derived from rapeseed oil preparations was slightly higher than that of rapeseed oil. Literature data on refined rapeseed oil report that the acid number of this oil is about $0.2 \mathrm{mg} \mathrm{KOH} \mathrm{g}^{-1}$ [22].

The Spearman's rank correlation $\left(r_{\mathrm{s}}\right)$ (a non-parametric correlation of non-normal distributions) was used to determine correlation between the studied parameters (Table 5).

Considering the results of the statistical analysis, a strong correlation was demonstrated between the oxidation induction time and the fatty acid content of the polyunsaturated, monounsaturated and saturated fatty acids extracted from pea protein-fat preparations. The PUFA content has the greatest influence on the induction time of fat extracted from these formulations. In the case of fats extracted from "fresh" formulas, the correlation coefficient between the induction time and the PUFA content can be defined as strong negative $(-0.92857)$, which means that samples with higher unsaturated fatty acid content were characterized by shorter induction time. In addition, a strong negative correlation was noticed between MUFA and induction time in the case of fats extracted from fresh formulations. On the other hand, there is a positive correlation between the content of saturated fatty acids and the trans isomers of fatty acids and the induction time of fat samples. Such correlations may indicate that the oxidative stability of fats in fresh protein-fat preparations is influenced primarily by the type of fatty acids contained in these formulations. Such a strong relationship between PUFA content and induction time was not observed for fats isolated from protein-fat preparations stored for 6 months. Therefore, the stability of these formulations may be influenced by other compounds, for example products of Maillard reaction, that may have developed during storage, as it was mentioned above. 


\section{Conclusions}

Our study indicates that the composition of fatty acids did not change during storage of the formulations at $25^{\circ} \mathrm{C}$ for 6 months. It could be stated that the studied wall system consisting of pea protein isolate in conjunction with carbohydrate was effective in stabilizing encapsulated fat during storage of spray-dried powder. There were differences in fatty acid profiles between formulations containing rapeseed oil and preparations with palm oil-rapeseed oil mixtures. Rapeseed oil microcapsules were characterized by a greater proportion of polyunsaturated fatty acids, while palm oil-rapeseed oil formulations contained higher levels of saturated fatty acids. Fats extracted from pea protein-fat formulations were characterized by satisfactory hydrolytic stability. There was a slight increase in the acid number after a 6-month storage period. Oxidative stability of microencapsulated fat was influenced by the type of fat. Fat extracted from fresh rapeseed oil capsules was the least stable (shorter induction time). The most stable fats after 6 months of storage were fats extracted from spray-dried fat-filled pea protein-based powders containing the mixture of palm and rapeseed oils formulated with inulin or trehalose.

Open Access This article is distributed under the terms of the Creative Commons Attribution 4.0 International License (http://creative commons.org/licenses/by/4.0/), which permits unrestricted use, distribution, and reproduction in any medium, provided you give appropriate credit to the original author(s) and the source, provide a link to the Creative Commons license, and indicate if changes were made.

\section{References}

1. Nesterenko A, Alric I, Silvestre F, Durrieu V. Vegetable proteins in microencapsulation: a review of recent interventions and their effectiveness. Ind Crop Prod. 2013;42:469-79.

2. Liu K. Expanding soybean food utilization. Food Technol. 2000;54(7):46-58.

3. Nunes MC, Batista P, Raymundo A, Alves MM, Sousa I. Vegetable proteins and milk puddings. Colloids Surf B Biointerfaces. 2003;31(1):21-2.

4. De Graaf LA, Harmsen PFH, Vereijken JM, Mönikes M. Requirements for non-food applications of pea proteins. A review. Mol Nutr Food Res. 2001;45(6):408-11.

5. Liu S, Elmer C, Low NH, Nickerson MT. Effect of $\mathrm{pH}$ on the functional behaviour of pea protein isolate-gum Arabic complexes. Food Res Int. 2010;43(2):489-95.

6. Pereira HVR, Saraiva KP, Carvalho LMJ, Andrade LR, Pedrosa C, Pierucci APTR. Legumes seeds protein isolates in the production of ascorbic acid microparticles. Food Res Int. 2009;42(1):115-21.

7. Pierucci APT, Andrade LR, Baptista EB, Volpato NM, RochaLeão MHM. New microencapsulation system for ascorbic acid using pea protein concentrate as coat protector. J Microencapsul. 2006;23(6):654-62.
8. Pierucci APT, Andrade LR, Farina M, Pedrosa C, Rocha-Leão MHM. Comparison of $\alpha$-tocopherol microparticles produced with different wall materials: pea protein a new interesting alternative. J Microencapsul. 2007;24(3):201-13.

9. Ducel V, Richard J, Saulnier P, Popineau Y, Boury F. Evidence and characterization of complex coacervates containing plant proteins: application to the microencapsulation of oil droplets. Colloids Surf A Physicochem Eng Asp. 2004;232(2):239-47.

10. Gharsallaoui A, Saurel R, Chambin O, Cases E, Voilley A, Cayot P. Utilisation of pectin coating to enhance spray-dry stability of pea protein-stabilised oil-in-water emulsions. Food Chem. 2010;122(2):447-54.

11. Auerbach M, Dedman AK. Bulking agents-multi-functional ingredients. In: O'Donell K, Kearsley M, editors. Sweeteners and sugar alternatives in food technology. New York: Wiley; 2012. p. 433-70.

12. Craig SAS, Holden JF, Troup JP, Auerbach MH, Frier H. Polydextrose as soluble fiber and complex carbohydrate. In: Ting SV, Rouseff RL, editors. Food science and technology. New York: Marcel Dekker; 1999. p. 229-48.

13. Röytiö H, Tiihonen K, Ouwehand AC. Digestive Health. In: O'Donnell K, Kearsley M, editors. Sweeteners and sugar alternatives in food technology. New York: Wiley; 2012. p. 63-73.

14. Flamm G, Glinsmann W, Kritchevsky D, Prosky L, Roberfroid M. Inulin and oligofructose as dietary fiber: a review of the evidence. Crit Rev Food Sci Nutr. 2001;41(5):353-62.

15. Roberfroid MB. Functional fibres: inulin and oligofructose. Int Food Ingred. 2000;3:31-2.

16. Domian E, Sułek A, Cenkier J, Kerschke A. Influence of agglomeration on physical characteristics and oxidative stability of spray-dried oil powder with milk protein and trehalose wall material. J Food Eng. 2014;125:34-43.

17. Higashiyama T, Richards AB. Trehalose. In: O’Donnell K, Kearsley M, editors. Sweeteners and sugar alternatives in food technology. New York: Wiley; 2012. p. 417-32.

18. Folch J, Lees M, Sloane Stanley GH. A simple method for the isolation and purification of total lipids from animal tissues. J Biol Chem. 1957;226(1):497-509.

19. Boselli E, Velazco V, Caboni MF, Lercker G. Pressurized liquid extraction of lipids for the determination of oxysterols in eggcontaining food. J Chromatogr A. 2001;917:239-44.

20. PN-EN ISO 660. Oleje i tłuszcze roślinne i zwierzęce. Oznaczanie liczby kwasowej. Animal and vegetable fats and oils. Determination of acid value. Polish Committee of Standardization (2010).

21. Mba OI, Dumontn MJ, Ngadinn M. Palm oil: processing, characterization and utilization in the food industry - a review. Food Biosci. 2015;10:26-41.

22. Wroniak M, Łukasik K, Maszewska M. Porównanie stabilności oksydatywnej wybranych olejów tłoczonych na zimno z olejami rafinowanymi. Zywn Nauk Technol Ja. 2006;46:214-21.

23. Augustin MA, Sanguansri L, Bode O. Maillard reaction products as encapsulants for fish oil powders. J Food Sci. 2006;71(2):E25-32.

24. Karaca AC, Nickerson M, Low NH. Microcapsulate production employing chickpea or lentil protein isolates and maltodextrin: physicochemical properties and oxidative protection of encapsulated flaxseed oil. Food Chem. 2013;139(1):448-57.

25. Gharsallaoui A, Saurel R, Chambin O, Voilley A. Pea (Pisum sativum, L.) protein isolate stabilized emulsions: a novel system for microencapsulation of lipophilic ingredients by spray drying. Food Bioprocess Technol. 2012;5(6):2211-21.

26. Nesterenko A, Alric I, Violleau F, Silvestre F, Durrieu V. The effect of vegetable protein modification on the microencapsulation process. Food Hydrocoll. 2014;41:95-102. 
27. Kowalski B, Gruczyńska E, Maciaszek K. Kinetics of rapeseed oil oxidation by pressure differential scanning calorimetry measurements. Eur J Lipid Sci Technol. 2000;102:337-41.

28. Tan CP, Che Man YB. Recent developments in differential scanning calorimetry for assessing oxidative deterioration of vegetable oils. Trends Food Sci Technol. 2002;13:312-8.

29. Kowalski B, Ratusz K, Kowalska D, Bekas W. Determination of the oxidative stability of vegetable oils by differential scanning calorimetry and Rancimat measurements. Eur J Lipid Sci Technol. 2004;106:165-9.

30. Velasco J, Andersen ML, Skibsted LH. Evaluation of oxidative stability of vegetable oils by monitoring the tendency to radical formation. A comparison of electron spin resonance spectroscopy with the Rancimat method and differential scanning calorimetry. Food Chem. 2004;85:624-32.

31. Ratusz K, Popis E, Ciemniewska-Żytkiewicz H, Wroniak M. Oxidative stability of camelina (Camelina sativa L.) oil using pressure differential scanning calorimetry and Rancimat method. J Therm Anal Calorim. 2016;126(1):343-51.

32. Bryś J, Flores Ines FV, Górska A, Wirkowska-Wojdyła M, Ostrowska-Ligęza E, Brys A. Use of GC and PDSC methods to characterize human milk fat substitutes obtained from lard and milk thistle oil mixtures. J Therm Anal Calorim. 2017;130(1):319-27.

33. Wirkowska-Wojdyła M, Bryś J, Górska A, Ostrowska-Ligęza E. Effect of enzymatic interesterification on physicochemical and thermal properties of fat used on cookies. LWT-Food Sci Technol. 2016;74:99-105.

34. Bryś J, Wirkowska M, Górska A, Ostrowska-Ligęza E, Brys A. Application of the calorimetric and spectroscopic methods in analytical evaluation of the human milk fat substitutes. J Therm Anal Calorim. 2014;118(2):841-8.

35. Bryś J, Wirkowska M, Górska A, Ostrowska-Ligęza E, Brys A, Koczoń P. The use of DSC and FT-IR spectroscopy for evaluation of oxidative stability of interesterified fats. J Therm Anal Calorim. 2013;112(1):481-7.

36. Wirkowska M, Ostrowska-Ligęza E, Górska A, Koczoń P. Thermal properties of fats extracted from powdered baby formulas. J Therm Anal Calorim. 2012;110(1):137-43.

37. Ciemniewska-Żytkiewicz H, Bryś J, Sujka K, Koczoń P. Assessment of the hazelnuts roasting process by pressure differential scanning calorimetry and MID-FT-IR spectroscopy. Food Anal Methods. 2015;8:2465-73.

38. Elizade BE, Rosa MD, Lerici CR. Effects of Maillard reaction volitiles products on lipid oxidation. J Am Oil Chem Soc. 1991;68:758-62.

39. Mensink MA, Frijlin HW, van der Voort Maarschalk K, Hinrichs WLJ. Inulin, a flexible oligosaccharide I: review of its physicochemical characteristics. Carbohydr Polym. 2015;130:405-19.

40. Michalska A, Zieliński H. Produkty reakcji Maillarda w żywności. Zywn Nauk Technol Ja. 2007;51:5-16.

41. Oku K, Watanabe H, Kubota M, Fukuda S, Kurimoto M, Tsujisaka Y, Komori M, Inoue Y, Sakurai M. NMR and quantum chemical study on the $\mathrm{OH} \cdots \pi$ and $\mathrm{CH} \cdots \mathrm{O}$ interactions between trehalose and unsaturated fatty acids: implication for the mechanism of antioxidant function of trehalose. J Am Oil Chem Soc. 2003;125(42):12739-48.

42. Hamam F, Shahidi F. Enzymatic acidolysis of an arachidonic acid single-cell oil with capric acid. J Am Oil Chem Soc. 2004;81:887-92. 